\title{
Electronic Cigarette Use Among High School Students and Its Association With Cigarette Use And Smoking Cessation, North Carolina Youth Tobacco Surveys, 2011 and 2013
}

\author{
Li-Ling Huang, PhD, MPH; Sarah D. Kowitt, MPH; Erin L. Sutfin, PhD; Tanha Patel, MPH; \\ Leah M. Ranney, PhD; Adam O. Goldstein, MD, MPH
}

Suggested citation for this article: Huang LL, Kowitt SD, Sutfin EL, Patel T, Ranney LM, Goldstein AO. Electronic Cigarette Use Among High School Students and Its Association With Cigarette Use And Smoking Cessation, North Carolina Youth Tobacco Surveys, 2011 and 2013. Prev Chronic Dis 2016; 13:150564. DOI: http://dx.doi.org/10.5888/pcd13.150564.

\section{PEER REVIEWED}

\section{Abstract}

\section{Introduction}

Although adolescent cigarette use continues to decline in the United States, electronic cigarette (e-cigarette) use among adolescents has escalated rapidly. This study assessed trends and patterns of e-cigarette use and concurrent cigarette smoking and the relationships between e-cigarette use and smoking cessation intentions and behaviors among high school students in North Carolina.

\section{Methods}

Data came from high school students who completed the schoolbased, cross-sectional North Carolina Youth Tobacco Survey in $2011(\mathrm{n}=4,791)$ and $2013(\mathrm{n}=4,092)$. This study assessed changes in prevalence of e-cigarette and cigarette use from 2011 through 2013, and cessation-related factors associated with those students' current and past use of e-cigarettes in 2013.

\section{Results}

The prevalence of current e-cigarette use (use in the past 30 days) significantly increased from $1.7 \%(95 \% \mathrm{CI}, 1.3 \%-2.2 \%)$ in 2011 to $7.7 \%(95 \% \mathrm{CI}, 5.9 \%-10.0 \%)$ in 2013 . Among dual users, cur- rent e-cigarette use was negatively associated with intention to quit cigarette smoking for good (relative risk ratio $[R R R]=0.51$; 95\% CI, 0.29-0.87) and with attempts to quit cigarette smoking in the past 12 months $(\mathrm{RRR}=0.69 ; 95 \% \mathrm{CI}, 0.49-0.97)$. Current ecigarette smokers were less likely than those who only smoked cigarettes to have ever abstained from cigarette smoking for 6 months $(\mathrm{RRR}=0.42 ; 95 \% \mathrm{CI}, 0.21-0.82)$ or 1 year $(\mathrm{RRR}=0.21$; 95\% CI, 0.09-0.51) and to have used any kind of aids for smoking cessation $(\mathrm{RRR}=0.46 ; 95 \% \mathrm{CI}, 0.29-0.74)$.

\section{Conclusion}

Public health practitioners and cessation clinic service providers should educate adolescents about the risks of using any nicotinecontaining products, including e-cigarettes, and provide adequate tobacco cessation resources and counseling to adolescent tobacco users.

\section{Introduction}

Electronic cigarettes (e-cigarettes) are devices that aerosolize liquid that contains nicotine, humectants, and flavoring agents and mimic the experience of cigarette smoking. These devices are being aggressively marketed as smoking cessation aids and as healthy alternatives to cigarette smoking $(1,2)$. Although e-cigarettes are not approved by the US Food and Drug Administration (FDA) as a cessation aid, they are perceived as healthier than cigarettes by adolescents (3), young adults $(4)$, and adults $(5,6)$. Adolescent cigarette smokers report that one reason they try e-cigarettes is because they want to quit cigarettes (3). But, unlike adults' reasons for using e-cigarettes, adolescents' top reason is not a desire to reduce cigarette smoking (6-10); for adolescents, curiosity, appealing flavors, and peer influences rank as higher reasons (3). 
Public health concerns about adolescent e-cigarette use have been raised because the adolescent's developing brain is particularly vulnerable to the negative effects of nicotine neurotoxin and nicotine dependence (11-13). Nicotine dependence may develop rapidly among at-risk youths who are still at relatively low levels of smoking, even before they progress to regular or daily smoking $(14,15)$. Longitudinal evidence shows that early emerging dependence symptoms in adolescence predict a greater predisposition for continued smoking behavior in young adulthood (16). High school students who are exposed to nicotine in early adolescence are also at higher risk for becoming highly nicotine dependent than are those exposed to nicotine later in adolescence, leading to more difficulty quitting (15). Having a better understanding of the relationship between e-cigarette use and smoking cessation intentions and behaviors among adolescents can inform FDA regulatory efforts on adolescent e-cigarette use, including communicating harmful health effects of e-cigarette use to youths, correcting misperceptions about their role in smoking cessation and nicotine addiction, and providing adolescents with adequate cessation resources.

Little data exists on how adolescents use e-cigarettes in an attempt to quit cigarette smoking. Recent cross-sectional data show that e-cigarette use among US adolescents was associated with lower odds of abstinence from cigarette use for 30 days or more (17). Planning to quit smoking cigarettes within the next year was positively associated with ever using e-cigarettes, but not with currently using e-cigarettes, and attempts to quit smoking were not associated with ever using or currently using e-cigarettes (17). Another US study of adolescent smokers reported that ever using ecigarettes was not associated with an intention to quit smoking (18). In a study of Korean adolescents, e-cigarette use was associated with higher odds of ever having attempted to quit smoking in the past 12 months among current cigarette smokers and lower odds of smoking cigarettes in the past 30 days among youths who had ever smoked cigarette, suggesting some youths may be using e-cigarettes as a cessation aid (19). These studies showed that current e-cigarette users were significantly less likely to have abstained from smoking cigarettes in the past 30 days; nevertheless, the relationships between e-cigarette use and intentions or attempts to quit cigarettes were mixed. Recent evidence supports the efficacy of psychosocial interventions for smoking cessation among adolescents, and some findings support the efficacy of nicotine replacement treatments (20). However, there is insufficient evidence to determine the efficacy of pharmacological treatments among adolescents (20).

We used cross-sectional data from the 2011 and 2013 North Carolina Youth Tobacco Survey (NCYTS) to examine relationships between using e-cigarettes and cigarette smoking among adolescents and to test whether e-cigarette use is associated with intention to quit cigarette smoking, attempts to quit, and various quit methods. In addition, we studied trends in adolescents' e-cigarette use over time.

\section{Methods}

\section{Data source}

The NCYTS is a voluntary, anonymous, school-based survey of middle and high school students administered biannually since 1999. The NCYTS survey uses a 2-stage cluster probability sampling design to produce a representative sample of students in grades 6 through 12 (21). Our study consisted of public high school students only (grades 9-12) because adolescents of high school age are more vulnerable than younger adolescents to experimenting with risky behaviors, including dual use of cigarette and e-cigarettes, The Centers for Disease Control and Prevention funded and approved the NCYTS, which is conducted to evaluate state tobacco control efforts. Our study, which used secondary data analysis, was reviewed by the Office of Human Research Ethics at the University of North Carolina, Chapel Hill, which determined that the study did not constitute human subjects research as defined under federal regulations 45 CFR 46.102 (d or f) and 21 CFR 56.102(c)(e)(l) and did not require institutional review board approval.

\section{Measurement}

Use of e-cigarettes and cigarettes. To assess cigarette smoking, we asked students whether they had ever tried cigarette smoking, even 1 or 2 puffs; when the last time was they smoked a cigarette, even 1 or 2 puffs; and how many days they smoked cigarettes during the past 30 days. Students who reported that they had ever smoked cigarettes, but not in the past 30 days, were categorized as "past users." Those who reported smoking cigarettes at least 1 day in the past 30 days were categorized as "current users." Current and past use of e-cigarettes was assessed by 2 questions: "In the past 30 days, which of the following tobacco products have you used on at least one day?" and "Which of the following tobacco products have you ever tried, even just one time?" Students who responded they had used "electronic cigarettes or e-cigarettes, such as Ruyan or NJOY" on at least 1 of the past 30 days were categorized as current users. Those who said they had ever used e-cigarettes, but not in the past 30 days, were categorized as past users. Students who never tried cigarettes or e-cigarettes were categorized as "never users." Students who both smoked cigarettes and used e-cigarettes in the past 30 days were categorized as current users of both. Students were also asked about their intention to try e-cigarettes with the question (asked in the 2013 survey only), "In the

\footnotetext{
The opinions expressed by authors contributing to this journal do not necessarily reflect the opinions of the U.S. Department of Health and Human Services, the Public Health Service, the Centers for Disease Control and Prevention, or the authors' affiliated institutions.
} 
next year, which of the following tobacco products do you think you will try?" Students who responded "electronic cigarettes or ecigarettes, such as Ruyan or NJOY" were considered as intending to try e-cigarettes.

These demographic variables were used as covariates in analysis to adjust for sex, grade $\left(9^{\text {th }}-12^{\text {th }}\right)$, and race/ethnicity (white, black, Hispanic, and other).

Intention to quit cigarette smoking. Intention to quit cigarette smoking was measured with the question "Do you want to stop smoking cigarettes for good?" with response options "Yes," "No," and "I do not smoke now." Quit attempts for cigarette smoking were measured with the question "During the past 12 months, how many times have you stopped smoking for 1 day or longer because you were trying to quit smoking cigarettes for good?" Students who chose 1 or more times (possible responses were 1 time, 2 times, 3-5 times, 6-9 times, and $\geq 10$ times) were categorized as having tried to quit smoking; those who chose "did not try to quit smoking cigarettes" were categorized as not having tried to quit smoking; those who reported not smoking cigarettes during the past 12 months were categorized as not smoking cigarettes. Length of last period of abstinence from cigarette smoking was based on responses to the question "When you last tried to quit for good, how long did you stay off cigarettes?" Response options were "less than 30 days," "30 days," "6 months," and "1 year."

Students were asked, "In the past 12 months, did you do any of the following to help you quit using tobacco of any kind for good?" Students could select 1 or more of the following responses (Table 1): "attended a program at my school," "attended a program in the community," "called a telephone help line or telephone quit line," "used nicotine gum," "used nicotine patch," "used any medicine to help quit," "visited an Internet quit site," "got help from family or friends," "used another method such as hypnosis or acupuncture," "tried to quit on my own or quit cold turkey," "I did not try to quit during the past 12 months," and "I did not use tobacco of any kind during the past 12 months." A variable was derived from answers to this question to classify students into 4 groups: "used any quit aid" for those who used any aid but not quit cold turkey, "quit cold turkey only" for those who answered "tried to quit on my own or quit cold turkey" only, "did not attempt to quit," or "did not use tobacco."

\section{Statistical analysis}

NCYTS data are statistically weighted to reflect the likelihood of sampling each student and to reduce bias by compensating for differing patterns of nonresponse. Data were analyzed by using STATA version 13.1 (STATA Corp) survey procedures to account for the complex survey design and sampling weights unless stated otherwise. We used $\chi^{2}$ tests to compare sample characteristics and to examine descriptive statistics for each covariate. Multinomial logistic regression analyses were conducted to examine associations between predictors (ie, cigarette use, quit intention, quit attempt, length of last abstinence period) and use of 3 outcome categories: never, past, and current e-cigarette use in 2013. Adjusted relative risk ratios (RRRs) were calculated in reference to the base group (ie, never e-cigarette users). Separate models were used for each cessation-related predictor because of collinearity between the predictors. All models were adjusted for sociodemographic variables.

\section{Results}

E-cigarette prevalence. Participants in the current study were 4,791 students from 90 high schools who participated in the 2011 NCYTS and 4,092 students from 83 high schools who participated in the 2013 NCYTS. The overall response rates combining school and student levels were $78.2 \%$ in 2011 and $67.8 \%$ in 2013 . Of the high school students in the 2011 and 2013 surveys, about half were male and more than $50 \%$ were non-Hispanic white (Table 2). The prevalence of current e-cigarette use among North Carolina high school students increased significantly, from 1.7\% (95\% CI, 1.3\%-2.2\%) in 2011 to 7.7 (95\% CI, 5.9\%-10.0\%) in 2013 while current cigarette use declined from $15.1 \%(95 \% \mathrm{CI}$, $13.7 \%-16.7 \%$ ) to $13.1 \%(95 \% \mathrm{CI}, 11.6 \%-14.7 \%$ ) (Table 2$)$. A notable increase occurred in the proportion of current e-cigarette users who had never smoked cigarettes from $2011(\mathrm{n}=7,7.8 \%$; $95 \% \mathrm{CI}, 6.6 \%-8.6 \%)$ to $2013(\mathrm{n}=26,11.6 \% ; 95 \% \mathrm{CI}$, $8.3 \%-16.0 \%$ ). Among students who reported in the 2013 survey that they thought they would try e-cigarettes in the next year, $20 \%$ had never smoked cigarettes. Concurrent use of cigarettes and ecigarettes was $4.4 \%$ (95\% CI, 3.3-5.8) among students surveyed in 2013, which was 3 times more than concurrent use of both products in $2011(1.3 \%$; 95\% CI, 1.0\%-1.8\%). Multinomial logistic regression analysis for both 2011 and 2013 confirmed that current cigarette use was strongly associated with both current and past e-cigarette use after adjusting for sociodemographic variables $(\mathrm{RRR}=18.68$; 95\% CI, 12.95-26.93 for current e-cigarette use in 2013; RRR $=46.17 ; 95 \% \mathrm{CI}, 28.98-73.55$ for past e-cigarette use in 2013) (Table 3).

Smoking cessation behaviors and e-cigarette use. The number of adolescents who got tobacco cessation help was low. Among those who responded that they used any method to quit tobacco for good in the past 12 months $(n=517)$, the majority $(n=357 ; 70.1 \%)$ reported trying to quit on their own or "quit cold turkey" (Table 1). Among those who reported using cessation aids, nicotine gum $(8.7 \%)$ and "help from family or friends" $(8.3 \%)$ were the most common methods reported by students, followed by "attended a

The opinions expressed by authors contributing to this journal do not necessarily reflect the opinions of the U.S. Department of Health and Human Services, the Public Health Service, the Centers for Disease Control and Prevention, or the authors' affiliated institutions. 
program" at their school or community. More than half of adolescents who reported that they used only "quitting cold turkey" ( $\mathrm{n}=$ $317)$ were either current e-cigarette users $(24.1 \%)$ or past e-cigarette users $(33.1 \%)$. Fewer of those who reported using at least one cessation aid to help them quit than those who reported using only "quit cold turkey," reported current e-cigarette use (15.5\%) or past e-cigarette use (16.2\%) (data not shown).

Correlates of current e-cigarette use. Table 4 shows factors significantly associated with current and past e-cigarette use in 2013. Overall, adolescents who were male, older (in higher grades), nonHispanic white or Hispanic (compared with non-Hispanic black), had no intention to quit smoking cigarettes, or made no attempt to quit smoking cigarettes were more likely to be current e-cigarette users. Adolescents who had ever abstained from cigarette smoking for long periods and used cessation aids were less likely to be current e-cigarette users than those who made no quit attempt in the past 12 months. For example, compared with students who did not want to stop smoking for good, those who did want to stop smoking were 0.51 times more likely than nonusers to be current e-cigarette users $(\mathrm{RRR}=0.51 ; 95 \% \mathrm{CI}, 0.29-0.87)$. Current e-cigarette use was negatively associated with trying to quit smoking cigarettes in the past 12 months $(\mathrm{RRR}=0.69 ; 95 \% \mathrm{CI}, 0.49-0.97)$ and ever abstinence from cigarette smoking for 6 months $(\mathrm{RRR}=$ $0.42 ; 95 \% \mathrm{CI}, 0.21-0.82)$ or 1 year $(\mathrm{RRR}=0.21 ; 95 \% \mathrm{CI}$, $0.09-0.51)$. No association existed between reported ever abstaining for less than 6 months and current e-cigarette use. Students who reported using any kind of cessation aid to quit using tobacco in the past 12 months, including medication and family and friend support, were less likely to be current e-cigarette users $(\mathrm{RRR}=$ 0.46 ; 95\% CI, 0.29-0.74).

Correlates of past e-cigarette use. Similar to current e-cigarette use, older, non-Hispanic white, and Hispanic students were more likely to be past e-cigarette users (Table 4). However, past e-cigarette use was not associated with adolescent intentions to quit cigarette smoking for good $(\mathrm{RRR}=0.83 ; 95 \% \mathrm{CI}, 0.50-1.36, P=.45)$, trying to quit smoking cigarettes in the past 12 months $(\mathrm{RRR}=$ $1.10 ; 95 \% \mathrm{CI}, 0.68-1.80, P=.68$ ), or ever abstinence from cigarette smoking. Students who quit cold turkey without any other cessation aids were more likely to be past e-cigarette users $(\mathrm{RRR}=$ $1.72 ; 95 \%$ CI, 1.21-2.45). Students who used cessation aids to help them quit tobacco were less likely to have used e-cigarettes in the past, but this association was moderate $(\mathrm{RR}=0.58 ; 95 \% \mathrm{CI}$, $0.33-1.02, P=.06)$.

\section{Discussion}

The prevalence of e-cigarette use and concurrent use of e-cigarettes and cigarettes among North Carolina adolescents increased rapidly from 2011 to 2013, consistent with national data $(17,22)$. Given that e-cigarettes have recently become the leading form of tobacco used by US adolescents (22), the rapid increase in e-cigarette use among North Carolina cigarette "never smokers" is also concerning. Longitudinal research began to monitor the relationship between e-cigarette use and initiating cigarette smoking over time and demonstrated that e-cigarette use leads to cigarette smoking, which could potentially become the initial source of nicotine exposure and create a new generation of adolescents with nicotine addiction $(23,24)$.

Our finding illustrated that North Carolina adolescent cigarette smokers who intended to quit or made any attempt to quit smoking cigarettes in the past 12 months were less likely to be current e-cigarette users. Such results are not surprising given that cessation is a far less commonly cited reason to use e-cigarettes among adolescents than adults (3). The relationship between e-cigarette use and intention and attempts to quit cigarette smoking were mixed across studies of US adolescents and Korean youths (17-19). The discrepant findings on quit intentions and attempts among the current and previous studies may be explained by several factors. Reasons for trying e-cigarettes may vary significantly by smoking cessation intentions and frequency of e-cigarette use, thereby making an association between cessation intentions and the use pattern of e-cigarettes nonsignificant. Research, including our study, often defines current e-cigarette use as any reported use in the past 30 days; thus, current e-cigarette users may include experimenters, unlike frequent users, who usually have different reasons for using e-cigarettes and will persist in using e-cigarettes (25). The definitions of quit intentions and attempts also vary across studies. Marked variation across studies in the measurement of adolescent e-cigarette use makes results difficult to interpret (26). Future research needs to use consistent and validated measures to assess quit intentions and attempts and to examine reasons for using e-cigarette by e-cigarette use frequency.

Similar to the findings of quit intentions and quit attempts, adolescent cigarette smokers who had ever abstained from cigarette smoking for 6 months or more were less likely to be current e-cigarette users. Future research should examine adolescents' reasons for using cigarettes to determine whether they use e-cigarettes to quit smoking cigarettes, whether they did not want to quit smoking entirely but sought a healthier alternative, or whether they simply experimented or used e-cigarettes for recreational reasons rather than for cessation reasons. Longitudinal research is needed to determine the causal relationship between e-cigarette use and cessation outcomes by tracking the patterns of cessation behaviors and e-cigarette use and examining reasons for using ecigarettes over time.

The opinions expressed by authors contributing to this journal do not necessarily reflect the opinions of the U.S. Department of Health and Human Services, the Public Health Service, the Centers for Disease Control and Prevention, or the authors' affiliated institutions. 
The majority of adolescent tobacco users reported that they either had tried to quit cold turkey or did not try to quit at all in the past 12 months. These adolescents may have felt invulnerable to health-threatening behaviors, felt optimistic about their chances of avoiding harm compared with adults' chances, believed they were less addicted to smoking, and believed quitting would be easy $(27,28)$. Our results also found that adolescents who reported they had used any cessation aids were less likely to be current e-cigarette users; on the other hand, those adolescents who tried quitting on their own were more likely to have used e-cigarettes in the past. It is unclear whether these adolescents experimented with e-cigarettes out of curiosity, or used e-cigarettes as a cessation aid or a healthier alternative. Future research should understand the role of e-cigarette use in adolescents' cessation behaviors by examining adolescents' reasons for using e-cigarettes and distinguish between e-cigarette motivated users (eg, quitting smoking as a goal-oriented reason) and e-cigarette experimenters (eg, curiosity as a nongoal-oriented reason) (9).

Additional limitations of this study should be noted. The limited terminology of the question on e-cigarette use may underestimate e-cigarette use because it does not include terms such as "vapes," which are commonly used by adolescents (29). The lack of a specific time frame for the measure of length of last abstinence limits our ability to examine relationships with current e-cigarette use. Our findings may not generalize to adolescents in populations other than North Carolina high school students; however, our results are similar to national results for adolescent tobacco use in the United States. Finally, because NCYTS uses a cross-sectional design, causal relationships cannot be determined, but many associations are consistent with previous cross-sectional data, providing important directions for future longitudinal research.

Our findings about rising dual use of e-cigarettes and cigarettes, along with associations between e-cigarette use and lower cessation intention and behaviors, have implications for public health practice and cessation clinic services. Our research supports FDA's recent announcement to extend its authority to regulate ecigarettes as tobacco products, which includes prohibiting unsubstantiated cessation aid claims and restricting the sale of e-cigarettes to adolescents under age 18 (30). The American Academy of Pediatrics called for stronger regulation of e-cigarettes, urged pediatricians to offer tobacco cessation counseling and FDA-approved treatments appropriate to an adolescent's level of addiction and readiness to change, and disapproved e-cigarette use as a recommended treatment product for tobacco dependence (13). Messages about negative effects of e-cigarette use, including the severity and rapid development of nicotine neurotoxin and addiction, on adolescents' health should be part of this counseling and youth tobacco control media campaigns as well.

\section{Acknowledgments}

This work was supported by the National Cancer Institute at the National Institutes of Health and the Center for Tobacco Products at the Food and Drug Administration (P50CA180907); and the Centers for Disease Control and Prevention (DP 14-1415). The content is solely the responsibility of the authors and does not necessarily represent the official views of the National Institutes of Health, the Food and Drug Administration, or the Centers for Disease Control and Prevention. The authors declare no conflicts of interest.

\section{Author Information}

Corresponding Author: Li-Ling Huang, PhD, MPH, Center for Regulatory Research on Tobacco Communication, Lineberger Comprehensive Cancer Center, University of North Carolina, Chapel Hill, Chapel Hill, NC 27599. Telephone: 919-966-2994. Email: huangl@email.unc.edu.

Author Affiliations: Sarah D. Kowitt, Gillings School of Global Public Health, University of North Carolina, Chapel Hill, North Carolina; Erin L. Sutfin, Department of Social Sciences and Health Policy, Wake Forest School of Medicine, Winston-Salem, North Carolina; Tanha Patel, Tobacco Prevention and Control Branch, North Carolina Department of Health and Human Services, Raleigh, North Carolina; Leah M. Ranney, Adam O. Goldstein, Center for Regulatory Research on Tobacco Communication, Lineberger Comprehensive Cancer Center, Tobacco Prevention and Evaluation Program, Department of Family Medicine, School of Medicine, University of North Carolina, Chapel Hill, North Carolina.

\section{References}

1. Grana RA, Ling PM. "Smoking revolution": a content analysis of electronic cigarette retail websites. Am J Prev Med 2014; 46(4):395-403.

2. Richardson A, Ganz O, Stalgaitis C, Abrams D, Vallone D. Noncombustible tobacco product advertising: how companies are selling the new face of tobacco. Nicotine Tob Res 2014; 16(5):606-14.

3. Kong G, Morean ME, Cavallo DA, Camenga DR, KrishnanSarin S. Reasons for electronic cigarette experimentation and discontinuation among adolescents and young adults. Nicotine Tob Res 2015;17(7):847-54.

The opinions expressed by authors contributing to this journal do not necessarily reflect the opinions of the U.S. Department of Health and Human Services, the Public Health Service, the Centers for Disease Control and Prevention, or the authors' affiliated institutions. 
4. Choi K, Forster J. Characteristics associated with awareness, perceptions, and use of electronic nicotine delivery systems among young US Midwestern adults. Am J Public Health 2013;103(3):556-61.

5. Dockrell M, Morrison R, Bauld L, McNeill A. E-cigarettes: prevalence and attitudes in Great Britain. Nicotine Tob Res 2013;15(10):1737-44

6. Adkison SE, O’Connor RJ, Bansal-Travers M, Hyland A, Borland R, Yong $\mathrm{H}-\mathrm{H}$, et al. Electronic nicotine delivery systems: international tobacco control four-country survey. Am J Prev Med 2013;44(3):207-15.

7. Etter J-F, Bullen C. Electronic cigarette: users profile, utilization, satisfaction and perceived efficacy. Addiction 2011;106(11):2017-28.

8. Vickerman KA, Carpenter KM, Altman T, Nash CM, Zbikowski SM. Use of electronic cigarettes among state tobacco cessation quitline callers. Nicotine Tob Res 2013; 15(10):1787-91.

9. Pepper JK, Ribisl KM, Emery SL, Brewer NT. Reasons for starting and stopping electronic cigarette use. Int J Environ Res Public Health 2014;11(10):10345-61.

10. Rahman MA, Hann N, Wilson A, Worrall-Carter L. Electronic cigarettes: patterns of use, health effects, use in smoking cessation and regulatory issues. Tob Induc Dis 2014;12(1):21.

11. Slotkin TA. Cholinergic systems in brain development and disruption by neurotoxicants: nicotine, environmental tobacco smoke, organophosphates. Toxicol Appl Pharmacol 2004; 198(2):132-51.

12. Walley SC, Jenssen BP;Section on Tobacco Control. Electronic nicotine delivery systems. Pediatrics 2015; 136(5):1018-26.

13. McRobbie H, Bullen C, Hartmann-Boyce J, Hajek P. Electronic cigarettes for smoking cessation and reduction. Cochrane Database Syst Rev 2014;12(12):CD010216.

14. DiFranza JR, Savageau JA, Fletcher K, O’Loughlin J, Pbert L, Ockene JK, et al. Symptoms of tobacco dependence after brief intermittent use: the Development and Assessment of Nicotine Dependence in Youth-2 study. Arch Pediatr Adolesc Med 2007;161(7):704-10.

15. Mermelstein R. Teen smoking cessation. Tob Control 2003; 12(90001,Suppl 1):i25-34.

16. Dierker L, Hedeker D, Rose J, Selya A, Mermelstein R. Early emerging nicotine dependence symptoms in adolescence predict daily smoking in young adulthood. Drug Alcohol Depend 2015;151:267-71.

17. Dutra LM, Glantz SA. Electronic cigarettes and conventional cigarette use among U.S. adolescents: a cross-sectional study. JAMA Pediatr 2014;168(7):610-7.
18. Park J-Y, Seo D-C, Lin H-C. E-Cigarette use and intention to initiate or quit smoking among US youths. Am J Public Health 2016;106(4):672-8.

19. Lee S, Grana RA, Glantz SA. Electronic cigarette use among Korean adolescents: a cross-sectional study of market penetration, dual use, and relationship to quit attempts and former smoking. J Adolesc Health 2014;54(6):684-90.

20. Simon P, Kong G, Cavallo DA, Krishnan-Sarin S. Update of adolescent smoking cessation interventions: 2009-2014. Curr Addict Rep 2015;2(1):15-23.

21. Proescholdbell SK, Summerlin-Long SK, Goldstein AO. Declining tobacco use among North Carolina middle and high school students: 1999-2007. N C Med J 2009;70(3):205-12.

22. Arrazola RA, Singh T, Corey CG, Husten CG, Neff LJ, Apelberg BJ, et al.;Centers for Disease Control and Prevention (CDC). Tobacco use among middle and high school students - United States, 2011-2014. MMWR Morb Mortal Wkly Rep 2015;64(14):381-5.

23. Primack BA, Soneji S, Stoolmiller M, Fine MJ, Sargent JD. Progression to traditional cigarette smoking after electronic cigarette use among US adolescents and young adults. JAMA Pediatr 2015;169(11):1018-23.

24. Leventhal AM, Strong DR, Kirkpatrick MG, Unger JB, Sussman S, Riggs NR, et al. Association of electronic cigarette use with initiation of combustible tobacco product smoking in early adolescence. JAMA 2015;314(7):700-7.

25. Amato MS, Boyle RG, Levy D. How to define e-cigarette prevalence? Finding clues in the use frequency distribution. Tob Control 2016;25(e1,e1):e24-9.

26. Echevarria C, Sinha IP. Heterogeneity in the measurement and reporting of outcomes in studies of electronic cigarette use in adolescents: a systematic analysis of observational studies. Tob Control 2016;tobaccocontrol-2015-052881. Published online Apr 29, 2016

27. Amos A, Wiltshire S, Haw S, McNeill A. Ambivalence and uncertainty: experiences of and attitudes towards addiction and smoking cessation in the mid-to-late teens. Health Educ Res 2006;21(2):181-91.

28. Cohn LD, Macfarlane S, Yanez C, Imai WK. Risk-perception: differences between adolescents and adults. Health Psychol 1995;14(3):217-22.

29. Wagoner KG, Cornacchione J, Wiseman KD, Teal R, Moracco KE, Sutfin EL. E-cigarettes, hookah pens and vapes: adolescent and young adult perceptions of electronic nicotine delivery systems. Nicotine Tob Res; 2016. Epub Mar 30, 2016.

\footnotetext{
The opinions expressed by authors contributing to this journal do not necessarily reflect the opinions of the U.S. Department of Health and Human Services, the Public Health Service, the Centers for Disease Control and Prevention, or the authors' affiliated institutions.
} 
30. Food and Drug Administration. FDA takes significant steps to protect Americans from dangers of tobacco through new regulation. Accessed May 5, 2016. http://www.fda.gov/ NewsEvents/Newsroom/Press Announcements/ ucm499234.htm. 


\section{Tables}

Table 1. Smoking Cessation Methods Attempted by Study Sample of Participants ( $N=517)^{\mathrm{a}}$ in Relation to E-Cigarette Use, 2013 North Carolina Youth Tobacco Survey

\begin{tabular}{|c|c|c|c|c|}
\hline \multirow[b]{2}{*}{ Cessation Method } & \multicolumn{4}{|c|}{ Used E-Cigarettes? } \\
\hline & $\begin{array}{l}\text { Total }^{\mathrm{a}} \\
\mathrm{N}(\%)^{\mathrm{b}}\end{array}$ & Never $(n=3,405), n(\%)$ & In Past $(n=397), n(\%)$ & Currently $(n=290), n(\%)$ \\
\hline Attended a program at my school & $33(6.6)$ & $23(66.5)$ & $6(20.0)$ & $4(13.5)$ \\
\hline Attended a program in the community & $36(6.9)$ & $32(90.2)$ & $3(5.7)$ & $1(4.1)$ \\
\hline Called a telephone help line or telephone quit line & $22(3.8)$ & $18(85.2)$ & $2(5.7)$ & $2(9.1)$ \\
\hline Used nicotine gum & $39(8.7)$ & $22(62.4)$ & $8(18.7)$ & $9(18.9)$ \\
\hline Used nicotine patch & $22(3.8)$ & $16(73.7)$ & $1(7.5)$ & $5(18.8)$ \\
\hline Used any medicine to help quit & $10(1.7)$ & $4(42.5)$ & $2(10.0)$ & $4(47.5)$ \\
\hline Visited an Internet quit site & $6(1.1)$ & $2(32.5)$ & $2(27.6)$ & $2(40.0)$ \\
\hline Got help from family or friends & $50(8.3)$ & $22(46.2)$ & $16(27.8)$ & $12(26.0)$ \\
\hline Used another method such as hypnosis or acupuncture & $4(0.5)$ & $3(84.4)$ & $1(15.6)$ & $0(0.0)$ \\
\hline Tried to quit on my own or quit cold turkey & $357(70.1)$ & $163(42.9)$ & $106(32.1)$ & $88(25.1)$ \\
\hline
\end{tabular}

${ }^{a}$ Study participants could choose all quit methods tried; therefore, number of responses (579) exceeds number of study respondents (517).

${ }^{\mathrm{b}}$ The percentages are weighted data based on the total of 517 participants. 
Table 2. Sociodemographic Characteristics of Participants in the $2011(\mathrm{~N}=4,791)$ and $2013(\mathrm{~N}=4,092)$ North Carolina Youth Tobacco Survey, by E-Cigarette Use

\begin{tabular}{|c|c|c|c|c|c|c|c|c|}
\hline \multirow[b]{3}{*}{ Sample Characteristics } & \multicolumn{4}{|c|}{2011} & \multicolumn{4}{|c|}{2013} \\
\hline & \multirow{2}{*}{$\begin{array}{c}\text { Full Sample } \\
\text { (n=4,791), } \\
\text { n (\% [95\% } \\
\text { Cl]) }\end{array}$} & \multicolumn{3}{|c|}{ E-Cigarette User } & \multirow[b]{2}{*}{$\begin{array}{c}\text { Full Sample } \\
\text { (n=4,092), } \\
\text { n (\% [95\% } \\
\text { Cl]) }\end{array}$} & \multicolumn{3}{|c|}{ E-Cigarette User } \\
\hline & & $\begin{array}{c}\text { Never }(n= \\
4,492), n(\%) \\
[95 \% \mathrm{Cl}])\end{array}$ & $\begin{array}{l}\text { Past }(n= \\
204), n(\%) \\
[95 \% \mathrm{Cl}])\end{array}$ & $\begin{array}{c}\text { Current }(n= \\
95), n(\%[95 \\
\% \text { CI]) }\end{array}$ & & $\begin{array}{c}\text { Never }(n= \\
3,405), n n(\% \\
[95 \% \mathrm{Cl}])\end{array}$ & $\begin{array}{l}\text { Past }(n= \\
397), n(\%) \\
[95 \% \mathrm{Cl}])\end{array}$ & $\begin{array}{c}\text { Current }(n= \\
290) n(\% \\
[95 \% \mathrm{Cl}])\end{array}$ \\
\hline Smoked cigarettes? & $4,791(100.0)$ & $\begin{array}{r}4,492(94.1 \\
[93.0-95.0])\end{array}$ & $\begin{array}{r}204(4.2 \\
[3.5-5.1])\end{array}$ & $\begin{array}{r}95(1.7 \\
[1.3-2.2])\end{array}$ & 4,092 (100.0) & $\begin{array}{r}3,405(82.2 \\
[78.0-85.7])\end{array}$ & $\begin{array}{r}397(10.1 \\
[8.2-12.5])\end{array}$ & $\begin{array}{r}290(7.7 \\
[5.9-10.0])\end{array}$ \\
\hline Never & $\begin{array}{r}2,878(61.3 \\
[58.2-64.3]) \\
\end{array}$ & $\begin{array}{r}2,863(64.7 \\
[61.8-67.5]) \\
\end{array}$ & $\begin{array}{r}8(5.8 \\
[2.3-14.0]) \\
\end{array}$ & $\begin{array}{r}7(7.8 \\
[6.6-8.6]) \\
\end{array}$ & $\begin{array}{r}2,544(63.2 \\
[61.2-65.2]) \\
\end{array}$ & $\begin{array}{r}2,449(73.5 \\
[70.5-76.3]) \\
\end{array}$ & $\begin{array}{r}69(18.5 \\
[13.6-24.7]) \\
\end{array}$ & $\begin{array}{r}26(11.6 \\
[8.3-16.0]) \\
\end{array}$ \\
\hline In the past & $\begin{array}{c}1,149(23.6 \\
21.6-25.8])\end{array}$ & $\begin{array}{c}1,060(23.2 \\
20.9-25.7])\end{array}$ & $\begin{array}{r}73(36.4 \\
[26.7-47.4]) \\
\end{array}$ & $\begin{array}{r}16(14.6 \\
[8.0-25.2])\end{array}$ & $\begin{array}{r}1,007(23.8 \\
[22.2-25.4])\end{array}$ & $\begin{array}{r}716(19.9 \\
[18.2-21.9])\end{array}$ & $\begin{array}{r}197(49.0 \\
[42.7-55.4])\end{array}$ & $\begin{array}{r}94(31.1 \\
[26.4-36.2])\end{array}$ \\
\hline Currently & $\begin{array}{r}764(15.1 \\
[13.7-16.7])\end{array}$ & $\begin{array}{r}569(12.1 \\
[10.9-13.5])\end{array}$ & $\begin{array}{r}123(57.8 \\
[47.2-67.8])\end{array}$ & $\begin{array}{r}72(77.6 \\
[65.8-86.1]) \\
\end{array}$ & $\begin{array}{r}541(13.1, \\
11.6-14.7]) \\
\end{array}$ & $\begin{array}{r}240(6.5 \\
[5.3-8.1])\end{array}$ & $\begin{array}{r}131(32.5 \\
[27.4-38.0])\end{array}$ & $\begin{array}{r}170(57.3 \\
[51.0-63.3]) \\
\end{array}$ \\
\hline \multicolumn{9}{|l|}{ Sex } \\
\hline Female & $\begin{array}{r}2,577(49.3 \\
[46.1-52.4])\end{array}$ & $\begin{array}{r}2,461(50.4 \\
[47.0-53.7]) \\
\end{array}$ & $\begin{array}{r}88(35.1 \\
[26.6-44.7]) \\
\end{array}$ & $\begin{array}{r}28(23.5 \\
[16.2-32.9]) \\
\end{array}$ & $\begin{array}{r}2,195(48.9 \\
[46.0-51.8]) \\
\end{array}$ & $\begin{array}{r}1,909(51.0 \\
[48.0-54.1])\end{array}$ & $\begin{array}{r}189(47.8 \\
[40.5-44.8]) \\
\end{array}$ & $\begin{array}{r}97(27.9 \\
[20.9-36.1]) \\
\end{array}$ \\
\hline Male & $\begin{array}{r}2,211(50.7 \\
[47.6-53.9])\end{array}$ & $\begin{array}{r}2,208(49.6 \\
[46.3-53.0]) \\
\end{array}$ & $\begin{array}{r}116(64.9 \\
[55.3-73.4])\end{array}$ & $\begin{array}{r}67(76.5 \\
[67.1-83.8]) \\
\end{array}$ & $\begin{array}{r}1,893(51.1 \\
[48.2-54.0]) \\
\end{array}$ & $\begin{array}{r}1,493(49.0 \\
[45.9-52.0])\end{array}$ & $\begin{array}{r}207(52.2 \\
[44.8-59.5]) \\
\end{array}$ & $\begin{array}{r}193(72.1 \\
[63.9-79.1]) \\
\end{array}$ \\
\hline \multicolumn{9}{|l|}{ Race/ethnicity } \\
\hline Non-Hispanic black & $\begin{array}{r}1,063(32.2 \\
25.3-40.0]) \\
\end{array}$ & $\begin{array}{r}1,041(33.5 \\
[26.3-41.5]) \\
\end{array}$ & $\begin{array}{r}17(11.8 \\
[6.2-21.3]) \\
\end{array}$ & $\begin{array}{r}5(10.2 \\
[4.1-23.1]) \\
\end{array}$ & $\begin{array}{r}1,132(27.3 \\
[23.9-31.0]) \\
\end{array}$ & $\begin{array}{r}1,028(30.2 \\
[26.4-34.3])\end{array}$ & $\begin{array}{r}67(17.9 \\
[13.4-23.5]) \\
\end{array}$ & $\begin{array}{r}37(8.8 \\
[5.1-14.6]) \\
\end{array}$ \\
\hline Non-Hispanic white & $\begin{array}{r}2,880(55.9 \\
[48.3-63.2])\end{array}$ & $\begin{array}{r}2,644(54.5 \\
[46.6-62.1])\end{array}$ & $\begin{array}{r}162(79.7 \\
[70.0-87.9])\end{array}$ & $\begin{array}{r}74(73.8 \\
[61.5-83.2])\end{array}$ & $\begin{array}{r}2,113(54.0 \\
[48.6-59.4])\end{array}$ & $\begin{array}{r}1,650(50.1 \\
[44.9-55.2])\end{array}$ & $\begin{array}{r}258(67.7 \\
[61.9-73.1])\end{array}$ & $\begin{array}{r}205(78.1 \\
[66.1-86.7])\end{array}$ \\
\hline Non-Hispanic other & $\begin{array}{r}232(3.9 \\
[3.1-4.9]) \\
\end{array}$ & $\begin{array}{r}215(3.9 \\
[3.1-50.0])\end{array}$ & $\begin{array}{r}11(3.8 \\
[1.7-8.0]) \\
\end{array}$ & $\begin{array}{r}6(4.5 \\
[1.5-12.6]) \\
\end{array}$ & $\begin{array}{r}224(7.5 \\
[5.4-10.3])\end{array}$ & $\begin{array}{r}192(8.1 \\
[6.2-10.9]) \\
\end{array}$ & $\begin{array}{r}19(4.5 \\
[1.9-10.2]) \\
\end{array}$ & $\begin{array}{r}13(4.7 \\
[2.1-10.4]) \\
\end{array}$ \\
\hline Hispanic & $\begin{array}{r}597(8.0 \\
[7.0-9.2])\end{array}$ & $\begin{array}{r}574(8.1 \\
[7.0-9.4])\end{array}$ & $\begin{array}{r}13(4.7 \\
[2.1-9.8])\end{array}$ & $\begin{array}{r}10(11.5 \\
[5.0-24.4])\end{array}$ & $\begin{array}{r}607(11.2 \\
[9.2-13.5])\end{array}$ & $\begin{array}{r}519(11.6 \\
[9.6-13.9])\end{array}$ & $\begin{array}{r}53(9.9 \\
[7.3-13.2])\end{array}$ & $\begin{array}{r}35(8.4 \\
[4.9-14.2]) \\
\end{array}$ \\
\hline \multicolumn{9}{|l|}{ Grade } \\
\hline 9th & $\begin{array}{r}1,463(29.9 \\
[23.3-37.4])\end{array}$ & $\begin{array}{r}1,395(30.7 \\
[23.9-38.5])\end{array}$ & $\begin{array}{r}46(14.9 \\
[9.2-23.3])\end{array}$ & $\begin{array}{r}22(18.9 \\
[10.4-31.6]) \\
\end{array}$ & $\begin{array}{r}1,193(28.8 \\
[22.4-36.2])\end{array}$ & $\begin{array}{r}1,069(31.5 \\
[25.3-38.5])\end{array}$ & $\begin{array}{r}72(16.8 \\
[11.1-24.6]) \\
\end{array}$ & $\begin{array}{r}52(15.4 \\
[8.7-25.8]) \\
\end{array}$ \\
\hline 10th & $\begin{array}{r}1,269(26.0 \\
[21.9-30.6])\end{array}$ & $\begin{array}{r}1,201(26.0 \\
[21.8-30.7])\end{array}$ & $\begin{array}{r}46(28.4 \\
[21.3-36.8])\end{array}$ & $\begin{array}{r}22(20.9 \\
[12.6-32.6])\end{array}$ & $\begin{array}{r}931(25.9 \\
[21.1-31.3])\end{array}$ & $\begin{array}{r}790(25.7 \\
[21.4-30.5])\end{array}$ & $\begin{array}{r}89(30.0 \\
[19.5-43.0])\end{array}$ & $\begin{array}{r}52(22.1 \\
[14.3-32.5])\end{array}$ \\
\hline 11th & $\begin{array}{r}1,081(23.3 \\
[19.0-28.3]) \\
\end{array}$ & $\begin{array}{r}1,010(23.2 \\
[18.8-28.2]) \\
\end{array}$ & $\begin{array}{r}53(27.4 \\
[18.4-38.6])\end{array}$ & $\begin{array}{r}18(23.2 \\
[14.4-35.1]) \\
\end{array}$ & $\begin{array}{r}957(23.4, \\
19.0-28.5])\end{array}$ & $\begin{array}{r}759(22.1 \\
[17.7-27.2])\end{array}$ & $\begin{array}{r}110(28.0 \\
{[22.6-34.1]}\end{array}$ & $\begin{array}{r}88(32.0 \\
[23.7-41.4]) \\
\end{array}$ \\
\hline 12th & $\begin{array}{r}970(20.8 \\
[17.3-24.6])\end{array}$ & $\begin{array}{r}878(20.1 \\
[16.8-23.9])\end{array}$ & $\begin{array}{r}59(29.3 \\
[21.1-39.1])\end{array}$ & $\begin{array}{r}33(37.1 \\
[24.8-51.3])\end{array}$ & $\begin{array}{r}1,000(21.9 \\
[18.3-26.1])\end{array}$ & $\begin{array}{r}776(20.7 \\
[16.9-25.2])\end{array}$ & $\begin{array}{r}126(25.2 \\
[16.6-36.4])\end{array}$ & $\begin{array}{r}98(30.6 \\
[23.7-38.5])\end{array}$ \\
\hline \multicolumn{9}{|l|}{ Quit-smoking intention } \\
\hline $\begin{array}{l}\text { Do not want to stop smoking } \\
\text { cigarettes for good }\end{array}$ & $\begin{array}{r}425(8.6 \\
[7.6-9.8])\end{array}$ & $\begin{array}{r}316(6.9 \\
[6.0-7.9])\end{array}$ & $\begin{array}{r}66(31.8 \\
[23.6-41.3])\end{array}$ & $\begin{array}{r}43(49.3 \\
[36.2-62.4])\end{array}$ & $\begin{array}{r}317(8.5 \\
[7.4-9.9])\end{array}$ & $\begin{array}{r}136(4.1 \\
[3.4-5.0])\end{array}$ & $\begin{array}{r}74(20.2 \\
[16.2-24.9])\end{array}$ & $\begin{array}{r}107(38.8 \\
[33.0-44.9])\end{array}$ \\
\hline $\begin{array}{l}\text { Want to stop smoking cigarettes } \\
\text { for good }\end{array}$ & $\begin{array}{r}355(7.2 \\
[6.1-8.5]) \\
\end{array}$ & $\begin{array}{r}275(5.9 \\
[5.0-6.9]) \\
\end{array}$ & $\begin{array}{r}59(29.2 \\
[21.7-38.0]) \\
\end{array}$ & $\begin{array}{r}21(24.8 \\
[14.6-39.0]) \\
\end{array}$ & $\begin{array}{r}253(5.9 \\
[4.8-7.2]) \\
\end{array}$ & $\begin{array}{r}129(3.4 \\
[2.6-4.5]) \\
\end{array}$ & $\begin{array}{r}65(15.2 \\
[9.6-23.1]) \\
\end{array}$ & $\begin{array}{r}59(18.6 \\
[13.9-24.5]) \\
\end{array}$ \\
\hline Do not smoke cigarettes now & $\begin{array}{r}3,889(84.2 \\
[82.4-85.9])\end{array}$ & $\begin{array}{r}3,787(87.3 \\
[85.7-88.6]) \\
\end{array}$ & $\begin{array}{r}76(39.1 \\
[29.4-49.6])\end{array}$ & $\begin{array}{r}26(25.9 \\
[16.8-37.9])\end{array}$ & $\begin{array}{r}3,355(85.6 \\
[84.1-87.0])\end{array}$ & $\begin{array}{r}2,990(92.4 \\
[90.6-93.9])\end{array}$ & $\begin{array}{r}246(64.6 \\
[57.1-71.5])\end{array}$ & $\begin{array}{r}119(42.6 \\
[37.1-48.4]) \\
\end{array}$ \\
\hline \multicolumn{9}{|c|}{ Attempted to quit in the past 12 months } \\
\hline $\begin{array}{l}\text { Did not try to quit smoking } \\
\text { cigarettes }\end{array}$ & $\begin{array}{r}431(8.5 \\
[7.4-9.9]) \\
\end{array}$ & $\begin{array}{r}340(7.2 \\
[6.1-8.4]) \\
\end{array}$ & $\begin{array}{r}51(23.5 \\
[17.0-31.7]) \\
\end{array}$ & $\begin{array}{r}40(47.9 \\
[36.2-57.9]) \\
\end{array}$ & $\begin{array}{r}304(7.7 \\
[6.3-9.4]) \\
\end{array}$ & $\begin{array}{r}136(4.0 \\
[3.4-4.6]) \\
\end{array}$ & $\begin{array}{r}69(19.4 \\
[13.9-26.5]) \\
\end{array}$ & $\begin{array}{r}99(32.1 \\
[28.2-36.3]) \\
\end{array}$ \\
\hline $\begin{array}{l}\text { Tried to quit smoking cigarettes } \\
\text { for good }\end{array}$ & $\begin{array}{r}631(13.1 \\
[11.4-14.9]) \\
\end{array}$ & $\begin{array}{r}499(11.0 \\
[9.6-12.6]) \\
\end{array}$ & $\begin{array}{r}98(49.0 \\
[38.3-57.8]) \\
\end{array}$ & $\begin{array}{r}34(36.7 \\
[26.0-48.9]) \\
\end{array}$ & $\begin{array}{r}481(11.9 \\
[10.6-13.4]) \\
\end{array}$ & $\begin{array}{r}230(6.6 \\
[5.2-8.4]) \\
\end{array}$ & $\begin{array}{r}140(34.6 \\
[25.9-44.6]) \\
\end{array}$ & $\begin{array}{r}111(38.4 \\
[33.0-44.0]) \\
\end{array}$ \\
\hline Did not smoke cigarettes & $\begin{array}{r}3,630(78.4 \\
[76.1-80.1]) \\
\end{array}$ & $\begin{array}{r}3,562(81.8 \\
[79.8-83.6])\end{array}$ & $\begin{array}{r}53(27.5 \\
[19.7-36.9])\end{array}$ & $\begin{array}{r}15(15.4 \\
[8.0-27.7])\end{array}$ & $\begin{array}{r}3,200(80.4 \\
[78.4-82.1]) \\
\end{array}$ & $\begin{array}{r}2,950(89.4 \\
[87.4-91.2])\end{array}$ & $\begin{array}{r}178(46.0 \\
[39.7-52.3])\end{array}$ & $\begin{array}{r}71(29.5 \\
[23.6-36.2]) \\
\end{array}$ \\
\hline
\end{tabular}

(continued on next page)

The opinions expressed by authors contributing to this journal do not necessarily reflect the opinions of the U.S. Department of Health and Human Services, the Public Health Service, the Centers for Disease Control and Prevention, or the authors' affiliated institutions. 
(continued)

Table 2. Sociodemographic Characteristics of Participants in the $2011(\mathrm{~N}=4,791)$ and $2013(\mathrm{~N}=4,092)$ North Carolina Youth Tobacco Survey, by E-Cigarette Use

\begin{tabular}{|c|c|c|c|c|c|c|c|c|}
\hline \multirow[b]{3}{*}{ Sample Characteristics } & \multicolumn{4}{|c|}{2011} & \multicolumn{4}{|c|}{2013} \\
\hline & \multirow{2}{*}{$\begin{array}{c}\text { Full Sample } \\
\text { (n=4,791), } \\
\text { n (\% [95\% } \\
\text { Cl]) }\end{array}$} & \multicolumn{3}{|c|}{ E-Cigarette User } & \multirow{2}{*}{$\begin{array}{c}\text { Full Sample } \\
\text { (n=4,092), } \\
\text { n (\% [95\% } \\
\text { Cl]) }\end{array}$} & \multicolumn{3}{|c|}{ E-Cigarette User } \\
\hline & & $\begin{array}{c}\text { Never }(n= \\
4,492), n(\% \\
[95 \% \mathrm{cl}])\end{array}$ & $\begin{array}{l}\text { Past }(n= \\
204), n(\% \\
[95 \% \mathrm{Cl}])\end{array}$ & $\begin{array}{c}\text { Current (n= } \\
\text { 95), n (\% [95 } \\
\% \text { Cl]) }\end{array}$ & & $\begin{array}{c}\text { Never }(n= \\
3,405), n(\% \\
[95 \% \mathrm{cl}])\end{array}$ & $\begin{array}{l}\text { Past }(n= \\
397), n(\% \\
[95 \% \mathrm{Cl}])\end{array}$ & $\begin{array}{c}\text { Current }(n= \\
290) n(\% \\
[95 \% \mathrm{Cl}])\end{array}$ \\
\hline \multicolumn{9}{|c|}{ Abstinence from cigarette use } \\
\hline Never tried to quit & $\begin{array}{r}469(9.6 \\
[8.3-11.1])\end{array}$ & $\begin{array}{r}386(8.4 \\
[7.1-9.8])\end{array}$ & $\begin{array}{r}45(21.9 \\
[15.2-30.6])\end{array}$ & $\begin{array}{r}38(48.7 \\
[39.7-57.7])\end{array}$ & $\begin{array}{r}333(8.5 \\
[7.2-9.9])\end{array}$ & $\begin{array}{r}168(4.8 \\
[4.1-5.6])\end{array}$ & $\begin{array}{r}73(20.5 \\
[15.8-26.3])\end{array}$ & $\begin{array}{r}92(32.3 \\
[27.0-38.2])\end{array}$ \\
\hline$<30$-day abstinence & $\begin{array}{r}383(7.7 \\
[6.3-9.2])\end{array}$ & $\begin{array}{r}285(6.1 \\
[4.9-7.6])\end{array}$ & $\begin{array}{r}74(34.4 \\
[25.8-44.1])\end{array}$ & $\begin{array}{r}24(27.0 \\
[25.8-44.1])\end{array}$ & $\begin{array}{r}301(7.2 \\
[6.3-8.3])\end{array}$ & $\begin{array}{r}158(4.5 \\
[3.6-5.7])\end{array}$ & $\begin{array}{r}67(15.2 \\
[10.9-20.8])\end{array}$ & $\begin{array}{r}76(26.1 \\
[21.6-31.2])\end{array}$ \\
\hline 30-day abstinence & $\begin{array}{r}151(2.9 \\
[2.4-3.6])\end{array}$ & $\begin{array}{r}132(2.7 \\
[2.2-3.2])\end{array}$ & $\begin{array}{r}14(8.5 \\
[5.5-12.7])\end{array}$ & $\begin{array}{r}5(3.3 \\
[1.2-8.5])\end{array}$ & $\begin{array}{r}107(2.8 \\
[2.1-3.8])\end{array}$ & $\begin{array}{r}47(1.5 \\
[0.9-2.3])\end{array}$ & $\begin{array}{r}39(9.6 \\
[5.8-15.4])\end{array}$ & $\begin{array}{r}21(8.6 \\
[5.0-14.2])\end{array}$ \\
\hline 6-month abstinence & $\begin{array}{r}105(2.1 \\
[1.6-2.6])\end{array}$ & $\begin{array}{r}82(1.7 \\
[1.3-2.3])\end{array}$ & $\begin{array}{r}19(9.0 \\
[5.3-14.8])\end{array}$ & $\begin{array}{r}4(2.9 \\
[1.0-7.8])\end{array}$ & $\begin{array}{r}96(2.1 \\
[1.6-2.9])\end{array}$ & $\begin{array}{r}53(1.4 \\
[1.0-2.0])\end{array}$ & $\begin{array}{r}30(6.8 \\
[4.0-11.3])\end{array}$ & $\begin{array}{r}13(4.1 \\
[2.2-7.8])\end{array}$ \\
\hline 1-year abstinence & $\begin{array}{r}234(4.7 \\
[4.0-5.5])\end{array}$ & $\begin{array}{r}207(4.5 \\
[3.7-5.4])\end{array}$ & $\begin{array}{r}22(10.1 \\
[5.8-16.9])\end{array}$ & $\begin{array}{r}5(4.2 \\
[1.3-12.2])\end{array}$ & $\begin{array}{r}187(4.6 \\
[3.8-5.4])\end{array}$ & $\begin{array}{r}123(3.4 \\
[2.6-4.3])\end{array}$ & $\begin{array}{r}143(13.3 \\
[10.2-17.3])\end{array}$ & $\begin{array}{r}21(5.8 \\
[2.9-11.2])\end{array}$ \\
\hline Never smoked cigarettes & $\begin{array}{r}3,350(73.1 \\
[70.2-75.7])\end{array}$ & $\begin{array}{r}3,310(76.6 \\
[74.0-79.1])\end{array}$ & $\begin{array}{r}27(16.2 \\
[10.3-24.4])\end{array}$ & $\begin{array}{r}13(14.0 \\
[7.7-24.0])\end{array}$ & $\begin{array}{r}2,954(74.8 \\
[72.8-76.7])\end{array}$ & $\begin{array}{r}2,770(84.5 \\
[82.0-86.8])\end{array}$ & $\begin{array}{r}129(34.6 \\
[28.0-41.9])\end{array}$ & $\begin{array}{r}55(23.1 \\
[17.5-30.0])\end{array}$ \\
\hline
\end{tabular}

The opinions expressed by authors contributing to this journal do not necessarily reflect the opinions of the U.S. Department of Health and Human Services, the Public Health Service, the Centers for Disease Control and Prevention, or the authors' affiliated institutions. 
Table 3. Association Between Past and Current E-Cigarette Use and Cigarette Smoking by Adolescents in the 2011 and 2013 North Carolina Youth Tobacco Surveys

\begin{tabular}{|l|r|r|r|r|}
\hline \multirow{2}{*}{ Smoked Cigarettes? } & \multicolumn{3}{|c|}{ E-cigarette Use, RRR (95\% Cl) } \\
\cline { 2 - 5 } & \multicolumn{2}{|c|}{$2011(\mathrm{n}=\mathbf{4 , 7 9 1 )}$} & \multicolumn{2}{|c|}{ 2013 (n=4,092) } \\
\cline { 2 - 5 } & Past Versus Never & Current Versus Never & Current Versus Never \\
\hline Never & $1.00[$ Reference] & $1.00[$ Reference] & $1.00[$ Reference] & $1.00[$ Reference] \\
\hline In the past & $20.95(6.14-71.45)$ & $4.97(1.69-14.63)$ & $9.66(6.82-13.69)$ & $9.21(6.38-13.28)$ \\
\hline Currently & $53.17(17.14-164.90)$ & $43.19(16.99-109.76)$ & $18.68(12.95-26.93)$ & $46.17(28.98-73.55)$ \\
\hline
\end{tabular}

Abbreviations: RRR: relative risk ratio; $\mathrm{Cl}$ : confidence interval.

${ }^{\text {a }}$ Adjusted for sex, race, and school grade. 
Table 4. Association between past or current e-cigarette use and sociodemographics and tobacco cessation behaviors in $2013 \mathrm{NC}$ Youth Tobacco Survey ( $\mathrm{n}=$ 4,092)

\begin{tabular}{|c|c|c|c|c|}
\hline \multirow[b]{2}{*}{ Factors } & \multicolumn{4}{|c|}{ RRR (95\% Cl) } \\
\hline & Past Versus Never E-Cigarette User & $P$ & Current Versus Never E-cigarette User & $P$ \\
\hline \multicolumn{5}{|l|}{ Sex } \\
\hline Female & \multicolumn{2}{|c|}{$1.00[$ Reference] } & \multicolumn{2}{|c|}{$1.00[$ Reference $]$} \\
\hline Male & $1.18(0.90-1.54)$ & .22 & $2.84(1.92-4.20)$ & $<.001$ \\
\hline \multicolumn{5}{|l|}{ Race } \\
\hline Non-Hispanic black & & 1.00 & & 1.00 \\
\hline Non-Hispanic white & $2.29(1.68-3.14)$ & $<.001$ & $5.42(2.83-10.36)$ & $<.001$ \\
\hline Non-Hispanic other & $0.95(0.42-2.19)$ & .91 & $2.06(0.86-4.98)$ & .10 \\
\hline Hispanic & $1.45(1.06-1.98)$ & .02 & $61(1.49-4.58)$ & .001 \\
\hline \multicolumn{5}{|l|}{ Grade } \\
\hline 9th & \multicolumn{2}{|c|}{$1.00[$ Reference] } & \multicolumn{2}{|c|}{$1.00[$ Reference $]$} \\
\hline 10th & $2.17(1.30-3.62)$ & .004 & $1.79(0.91-3.51)$ & .09 \\
\hline 11th & $2.40(1.66-3.45)$ & $<.001$ & $3.07(2.04-4.62)$ & $<.001$ \\
\hline 12th & $2.26(1.54-3.32)$ & $<.001$ & $3.07(1.89-4.99)$ & $<.001$ \\
\hline \multicolumn{5}{|l|}{ Intention to quit ${ }^{\mathrm{a}}$} \\
\hline Do not want to stop smoking cigarettes for good & \multicolumn{2}{|c|}{$1.00[$ Reference $]$} & \multicolumn{2}{|c|}{$1.00[$ Reference $]$} \\
\hline Want to stop smoking cigarettes for good & $0.83(0.50-1.36)$ & .45 & $0.51(0.29-0.87)$ & .02 \\
\hline Do not smoke cigarettes now & $0.14(0.10-0.21)$ & $<.001$ & $0.05(0.03-0.09)$ & $<.001$ \\
\hline \multicolumn{5}{|l|}{ Attempted to quit in the past 12 months ${ }^{a}$} \\
\hline Did not try to quit smoking cigarettes for good & \multicolumn{2}{|c|}{$1.00[$ Reference $]$} & \multicolumn{2}{|c|}{$1.00[$ Reference $]$} \\
\hline $\begin{array}{l}\text { Tried to quit smoking } \\
\text { cigarettes for good }\end{array}$ & $1.10(0.68-1.80)$ & .68 & $0.69(0.49-0.97)$ & .04 \\
\hline Did not smoke cigarettes & $0.11(0.07-0.17)$ & $<.001$ & $0.05(0.03-0.06)$ & $<.001$ \\
\hline \multicolumn{5}{|l|}{ Last abstinence from cigarette use ${ }^{a}$} \\
\hline Never tried to quit & \multicolumn{2}{|c|}{$1.00[$ Reference $]$} & \multicolumn{2}{|c|}{$1.00[$ Reference $]$} \\
\hline$<30$-day abstinence & $0.76(0.41-1.42)$ & .39 & $0.76(0.51-1.15)$ & .19 \\
\hline 30-day abstinence & $1.54(0.70-3.41)$ & .28 & $0.83(0.34-2.00)$ & .67 \\
\hline 6-month abstinence & $1.17(0.57-2.36)$ & .67 & $0.42(0.21-0.82)$ & .01 \\
\hline 1-year abstinence & $0.88(0.63-1.23)$ & .44 & $0.21(0.09-0.51)$ & .001 \\
\hline Never smoked cigarettes & $0.10(0.07-0.14)$ & $<.001$ & $0.04(0.03-0.07)$ & $<.001$ \\
\hline \multicolumn{5}{|l|}{ Used quit aid in the last 12 months $^{a}$} \\
\hline Did not attempt to quit & \multicolumn{2}{|c|}{$1.00[$ Reference] } & \multicolumn{2}{|c|}{$1.00[$ Reference $]$} \\
\hline Quit cold turkey only & $1.72(1.21-2.45)$ & .003 & $1.04(0.71-1.52)$ & .83 \\
\hline Used any quit aid & $0.58(0.33-1.02)$ & .06 & $0.46(0.29-0.74)$ & .002 \\
\hline Did not use tobacco & $0.15(0.11-0.19)$ & $<.001$ & $0.00(0.00-0.00)$ & $<.001$ \\
\hline
\end{tabular}

Abbreviations: $\mathrm{Cl}$, confidence interval; RRR, relative risk ratio.

${ }^{\text {a }}$ Separate models were used for each cessation-related predictor and were adjusted for sex, race, and grade.

The opinions expressed by authors contributing to this journal do not necessarily reflect the opinions of the U.S. Department of Health and Human Services, the Public Health Service, the Centers for Disease Control and Prevention, or the authors' affiliated institutions. 